\title{
Risk Assessment of Afforestation and Reforestation
}

\section{Processes}

\author{
Teodors Blija ${ }^{1}$ and Anita Blija ${ }^{2}$ \\ 1. Department of Silviculture, Forest Faculty, Latvia University of Agriculture, Jelgava, Latvia \\ 2. Department of Nutrition, Faculty of Food Technology, Latvia University of Agriculture, Jelgava, Latvia
}

\begin{abstract}
Relatively simple forest planting process in real life is not so simple. Its relationships with various environmental, climatic, ecological and other environmental conditions cause a lot of problems. In this paper, hazard analysis critical control point (HACCP) analysis was conducted to identify the critical control points in forest regeneration process. As a result, it has a positive effect on the entire reforestation result. Critical control points will enable timely to draw attention to possible errors or incorrect solutions and consequently improve afforestation or restoration quality. Reforestation often occurs mistakes that lead to an unsuccessful reforestation. To remedy this situation, these critical control points should be identified with HAACP analysis.
\end{abstract}

Key words: Risk assessment, afforestation and reforestation processes, critical control points, deception of the consumers.

\section{Introduction}

Lately, more and more attention is paid to cases of misleading forest consumers. Why this issue was activated?

Contractors of forest form a new company with new services, but also generate new risks that lead to known or unknown risks or problems, thus leading to the potential of misleading forest owners (service consumer). How to recognize or identify the probability of risk to potential forest owners (service consumer) deception?

In the forest management, production of the final product is wood of high quality. In order to achieve this goal, it is necessary to ensure an optimal quality of the wood production process. Forest management has introduced full traceability of forest planting. Such forest management has introduced the traceability of product quality and thus can prevent mistakes in technology to increase profits [1].

Reforestation is often flawed. This leads to the fact that the forest areas do not produce wood. The

Corresponding author: Teodors Blija, M.Sc., research fields: afforestation, reforestation, nursery and forest soil preparation. situation should be corrected by the identification of critical control points using the method of hazard analysis critical control point (HACCP) analysis. Critical control point identification makes it possible to avoid the mistakes of forest renewal. Thus, this paper aimed to identify the critical control points in forest regeneration process by HACCP.

\section{Materials and Methods}

The most important step of forest management is a reforestation or afforestation. The success or failure depends on future forest regeneration timber cultivation in 100 years time. HACCP analysis was carried out to improve reforestation process by the critical control point identification.

Using HACCP method can identify those stages which are the possible risks. The critical control points make it possible to change the scale of the risk of forest complex decision scheme.

\subsection{HACCP Method}

At commencement of the study, to read up more literature on risk control and management system (HACCP) techniques in the food industry [1-3]. 
Second, the forest biological diversity, stability and quality in HACCP system were outlined. The HACCP system can analyze forest biological diversity, stability and quality. Third, develop an identification structure by critical point (CP), which gives additional explanations for sustainable forest management in all aspects and constitute a further focus of the study content.

HACCP stands for the risk identification in the critical point (phase) and management of the whole process [4]. HACCP is a tool that the company, institution or process management allows risk causes to control with more structural approach than that is possible with traditional inspection and quality control procedures [5]. It is potentially able to identify the product, process or system process during which so far has not experienced failure and are therefore especially useful for emerging technologies.

To start the use of HACCP based systems, it is first to carry out risk assessment of forest management and monitoring process. Risk assessment is a process in which identify the risk of probable causes [6] and assess the causes of the possible effects on the forest management process [7] in general. Eliminate the two important factors related to risk assessment: (1) risk likelihood or probability of causation and (2) the consequences if it is realized.

Risk assessment is carried out by the analytic work. Risk assessment includes both quantitative and qualitative risk assessment. Risk assessment can be described by administrative system, education of forest owners, property size, economic opportunities for forest management, forest access, technology used, etc..

The traditional evaluation model consists of the cause of the risk identification, characterization, practical expressions of evaluation and characterization [8].

There is a very sophisticated risk assessment scale. From appearing in the literature, this is the simplest, which described the quantified risk assessment scale for each considered point.

\subsection{Using Risk Analysis}

The identification of critical control points (CCPs) can also be done by using the risk analysis and the obtained risk categories (Tables 1 and 2).

\section{Results and Discussion}

Forest re-cultivation of non-agricultural land is afforestation. Afforestation is carried out in areas where the forest has never been climbed. Before the start of work, the following should be assessed: (1) soil fertility characteristics of new forest area, (2) climate characteristics and (3) tree species of plants for compliance with a particular location.

Reforestation is clear-cut areas. Also, in these areas, there are many obstacles for the quality of forest regeneration. Most of the errors are leaving the area for natural restoration. There are still a number of opportunities to make mistakes in forest regeneration.

Table 1 Influence of category of risk assessment.

\begin{tabular}{ll}
\hline Risk category & Influence \\
\hline 1 & No additional measures or controls required \\
$2-3$ & Control points \\
$\geq 4$ & Critical control point \\
\hline
\end{tabular}

Table 2 The scale of risk assessment.

\begin{tabular}{llllll}
\hline \multirow{4}{*}{ Probability } & High & 4 & 5 & 6 & 7 \\
& Real & 3 & 4 & 5 & 6 \\
& Small & 2 & 3 & 4 & 5 \\
\hline Effect & Very small & 1 & 2 & 3 & 4 \\
\hline
\end{tabular}

Source: Ref. [2]. 
Each of the above reforestation processes is slightly different approach, but the main job process is similar. Consequently, it offers opportunities for various reconstruction processes in comparative analyzes and determination of critical control points.

\subsection{Reforestation}

Lately, often natural reforestation is carried out with or without the help of seed trees. The results are not always good. HACCP analysis must be carried out to look for the critical control points. With critical control point evaluation, it is possible to prevent the failure of forest regeneration.

The risk assessment processes in Tables 3 and 4 show that a very important critical control point in natural forest regeneration is without soil preparation. Analysis suggests that the natural forest regeneration without soil preparation in practice should be abandoned because of high risks. Reforestation with plants shows identical critical control points (Table 5). Consequently, it can be concluded that reforestation without soil preparation is not recommended.

\subsection{Afforestation}

Unmanaged area overgrowing with uncontrolled tree species is a major problem. Therefore, such a risk can not be relied upon. Afforestation will be reviewed with plants (Table 6).

By HACCP analysis and critical control point identification, it can be concluded that without soil preparation, reforestation and afforestation can not be successful.

There are still some reforestation process steps, which should be given special attention to.

Forest restoration is a complex set of measures [9], where each of the technological stages is important due to a real risk [10], and make it difficult to control [7].

Table 3 Natural forest regeneration by seed trees.

\begin{tabular}{llll}
\hline Hazard identification & Risk assessment & Hazard identification & Risk assessment \\
\hline Without soil preparation & $6-7$ & With soil preparation & $1-6$ \\
\hline Forest soil type & $5-6$ & Forest soil type & $2-3$ \\
\hline Target species of trees & $5-6$ & Target species of trees & $2-3$ \\
\hline $\begin{array}{l}\text { Forest regeneration } \\
\text { time (5-10 years) }\end{array}$ & $5-6$ & $\begin{array}{l}\text { Forest regeneration } \\
\text { time (3-6 years) }\end{array}$ & $3-4$ \\
\hline
\end{tabular}

Table 4 Natural forest regeneration without seed trees.

\begin{tabular}{llll}
\hline Hazard identification & Risk assessment & Hazard identification & Risk assessment \\
\hline Without soil preparation & 7 & With soil preparation & $4-6$ \\
\hline Forest soil type & $6-7$ & Forest soil type & $4-5$ \\
\hline Target species of trees & $6-7$ & Target species of trees & $4-5$ \\
\hline $\begin{array}{l}\text { Forest regeneration } \\
\text { time (5-10 years) }\end{array}$ & $5-6$ & $\begin{array}{l}\text { Forest regeneration } \\
\text { time (3-6 years) }\end{array}$ & $4-5$ \\
\hline
\end{tabular}

Table 5 Reforestation with plants.

\begin{tabular}{llll}
\hline Hazard identification & Risk assessment & Hazard identification & Risk assessment \\
\hline Without soil preparation & $5-6$ & With soil preparation & $2-6$ \\
\hline Planting & $4-5$ & Planting & $1-3$ \\
\hline Forest soil type & $3-4$ & Forest soil type & $2-3$ \\
\hline Target species of trees & $1-3$ & Target species of trees & 1 \\
\hline $\begin{array}{l}\text { Forest regeneration } \\
\text { time (3-5 years) }\end{array}$ & $3-4$ & $\begin{array}{l}\text { Forest regeneration } \\
\text { time (2-4 years) }\end{array}$ & $1-2$ \\
\hline
\end{tabular}


Table 6 Afforestation with plants.

\begin{tabular}{llll}
\hline Hazard identification & Risk assessment & Hazard identification & Risk assessment \\
\hline Without soil preparation & $5-6$ & With soil preparation & $3-6$ \\
\hline Planting & $4-5$ & Planting & $2-3$ \\
\hline Forest soil type & $3-4$ & Forest soil type & $2-3$ \\
\hline Target species of trees & $3-4$ & Target species of trees & 1 \\
\hline $\begin{array}{l}\text { Forest regeneration } \\
\text { time (5-7 years) }\end{array}$ & $4-5$ & $\begin{array}{l}\text { Forest regeneration } \\
\text { time (2-4 years) }\end{array}$ & $1-2$ \\
\hline
\end{tabular}

The identified risk values should not be further processed statistically. Risk category should be assessed in the context of stages of the process [11]. This risk analysis was listed and analyzed by classical reforestation [12] and afforestation [13] technology-related stages.

Risk analysis is a great application. This makes it possible to assess the planned process of realization of the risk and prevention options. For example, unmanaged area overgrowing with uncontrolled tree species are at high risk 7 , this area is economically inefficient and loss.

Risk analysis is often in the large range of assessment and their impact leaves a number of factors. For instance, risk assessment of soil preparation ranges in 1-6, thus producing the question "why show such a high risk difference?"

There are several factors affecting on the results of risk assessment range, such as: (1) inappropriate tillage kind of choice, (2) inappropriate use of soils processing facility, (3) factory misinformation about the functioning of the mechanism and (4) performers lack of specific knowledge.

In fact, it is a two-stage consumer deception of "manufacturer's factory $\longrightarrow$ a contractor $\longrightarrow$ consumer".

It is already further research of the subject.

In general, risk analysis provides insight into the planned reforestation or afforestation process risk. This, in turn, allows you to choose the technological processes with a lower level of risk and to carry out a risk analysis at critical control points.

Risk analysis is another good feature. It allows non-experts to explain the increased risk and the need for investment risk point.

\section{Conclusions and Recommendations}

After analysis, it can be seen that forest renovation without soil preparation is a very risky venture. A big risk is in the renovation of forest trees or sowing seeds. The best of forest renovation options is forest planting in areas where the soil is prepared. It greatly reduces the risk. Forest renovation will be subjected to high risk when sowing or planting performs on overgrown areas. According to the study, the forest soil treatment is an important critical control point. Forest renovation will be successful and less risky if you apply forest soil treatments.

Risk analysis can take a forest specialist with broad and deep knowledge in the industry. Risk analysis reveals the stages of the process with a variety of impact risks. It allows you to choose the technological processes with a lower risk and allows the adjustment process in order to reduce or eliminate potential risks. This adjustment allows you to redirect financial resources for investment in technological process. Risk analysis is also able to detect misleading the consumer and find the opportunity to explain the increased risk of non-experts and the need for investment.

\section{References}

[1] Blija, A. 2005. "Risk Analysis and Control Information System for Public Companies." In Risks in Agriculture and Private Forestry, edited by Rivža, P., and Spoga, K. Jelgava: LUA, 303-19. (in Latvian)

[2] Flynn, J. 2000. HACCP 2000. London: International Thomson Business Press.

[3] FAO. 2002. "Risk Management." In Proceedings of FAO/WHO Global Forum of Food Safety Regulations 
"Improving Efficiency and Transparency in Food Safety Systems Sharing Experiences”, 119-52.

[4] Skudra, L. 2005. "Hazard Assessment and Risk Identification in Food Enterprises." In Risks in Agriculture and Private Forestry, edited by Rivža, P., and Špoǵis, K. Jelgava: LUA, 269-319. (in Latvian)

[5] Arhipova, I., Arhipovs, S., Blija, A., Dolgoṇenko, V., Dumpe, D., Galaburda, R., Kārkliņa, D., and Zacepins, A. 2006. Risk Analysis Applications Processed Fruit and Vegetable Sector Produced in Product Safety Evaluation and Methodology Development HAACP Computerized System for Quality, edited by Rivža, P., and Spoga, K. Jelgava: LUA, 362-404. (in Latvian)

[6] Food and Agriculture Organization of the United Nations (FAO). 1998. A Training Manual on Food Hygiene and the Hazarded Analysis and Critical Control Point (HACCP) System. Rome: FAO, 107-232.

[7] Kaktiňš, J., Arhipova, I., and Blija, T. 2007. Risk Management Systems and Technology Development in the Private Forestry, edited by Rivža, P., and Spogis, K. Jelgava: LUA, 405-38. (in Latvian)

[8] National Advisory Committee on Criteria for Foods. 1998. "Hazard Analysis and Critical Control Point Principles and Application Guidelines." J. Food Prot. 61 (9): 1246-59.

[9] Gasiņš, L. 1975. Forestry Work Mechanization. Rīga: Zvaigzne, 325. (in Latvian)

[10] Mangalis, I., and Liepa, J. 1980. Artificial Forest Restoration Technology. Rīga: LatZTIZPI, 56. (in Latvian)

[11] Blija, T. 2012. "Critical Control Points (CCP) of Risk Determination and Control Systems of HACCP Implementation in the Private Forestry." Forestry Ideas 18: 104-9.

[12] Mangalis, I. 1989. Forest Culture. Rīga: Zvaigzne, 347. (in Latvian)

[13] Mangalis, I. 2004. Reforestation and Afforestation. Rīga: Zvaigzne, 455. (in Latvian) 